\title{
Iwona Staszkiewicz-Grabarczyk
}

Uniwersytet Warmińsko-Mazurski w Olsztynie

\section{Uwarunkowania prawne polityki społecznej wobec osób z niepełnosprawnością}

Niepełnosprawność zajmuje istotne miejsce w polityce społecznej każdego państwa. Dane statystyczne wskazują, że co dziesiątą osobę w Polsce dotyka ten problem. Mimo, iż zauważa się działania zmierzające do poprawy sytuacji osób niepełnosprawnych, likwidacji wszelkich barier oraz mentalności społeczeństwa to modyfikacji powinny ulec reguły polityki społecznej, które pozwoliłyby na włączenie osób z niepełnosprawnościami w główny nurt różnych obszarów życia społecznego, na zwiększenie skuteczności działań instytucji wspierających te osoby oraz na wzrost upodmiotowienia środowisk niepełnosprawnych. W tekście przedstawione zostaną definicje polityki społecznej, cele oraz jej istota w odniesieniu do niepełnosprawności. Zaprezentowana kategoria pojęciowa polityki społecznej odnosić się będzie do podmiotów globalnych, europejskich, państwowych oraz niepublicznych. Uwarunkowania prawne niepełnosprawności w polityce społeczną zostaną przedstawione na gruncie międzynarodowym, europejskim oraz krajowym.

Słowa kluczowe: polityka społeczna, podmioty polityki społecznej, wsparcie społeczne, niepełnosprawność, uwarunkowania prawne

\section{Legal circumstances of social policy towards people with disabilities}

The subject of disability is of significant importance in social policy of every country. Statistical data show that 1 in 10 people in Poland suffers from this problem. Although there are evident efforts to make disabled people's lives better, to remove barriers and to change mentality of society, bigger efforts should be made to modify the regulations of social policy. That would allow to incorporate the disabled to the mainstream of different areas of social life, increase the efficiency of practices of institutions supporting people and strenghten the subjectivity of people with disabilities. The text presents definitions of social policy, its objectives and significance towards disability. Presented concepts of social policy consider global, European, state and private subjects. Legal conditions of disability in social policy are presented in the international, European and state context.

Keywords: social policy, social policy subjects, social support, disability, legal conditions 


\section{Wprowadzenie}

Nowoczesna polityka społeczna, odnosząca się do człowieka niepełnosprawnego, ogniskuje wokół pojęcia integracji, tzn. dotyczy „działań podmiotów publicznych i ich partnerów społecznych realizowanych zarówno na szczeblu centralnym, jaki lokalnym, mających na celu stworzenie warunków pełnego i równorzędnego funkcjonowania osób niepełnosprawnych we wszystkich sferach życia społeczno-gospodarczego" [Marska-Dzioba 2011: 351].

Radykalna zmiana podejścia do niepełnosprawności znalazła odzwierciedlenie w definiowaniu zjawiska, uznając, iż „niepełnosprawność nie jest (...) immanentną cechą jednostki, która z racji uszkodzeń lub wad fizycznych czy psychicznych nie jest $\mathrm{w}$ stanie funkcjonować we właściwy sposób w społeczeństwie. Jest właściwością sposobu zorganizowania społeczeństwa, które odpowiada na fakt istnienia ludzi z ograniczeniami fizycznymi lub psychicznymi w sposób, który nie stwarza im warunków zapewniających możliwość uczestnictwa w różnego rodzaju aktywnościach społecznych" [Gąciarz 2014a: 19].

Definiując politykę społeczną należy zwrócić uwagę na złożoność pojęcia. Zdaniem Kazimierza Obuchowskiego jest ona "teorią i praktyką pomagania ludziom w osiąganiu określonego poziomu jakości życia, zachowania osiągniętego poziomu oraz obrony przed zagrożeniami jakości życia" [Obuchowski 1999: 73]. Odnosząc się do kwestii praktycznej Julian Auleytner politykę społeczną określa jako "działalność państwa, samorządu i organizacji pozarządowych" [Auleytner 2000: 169] w celu wyrównywania "drastycznych różnic socjalnych między obywatelami, dawanie im równych szans i asekurowanie ich przed skutkami ryzyka socjalnego" [Ibidem]. Z kolei teoria polityki społecznej jest nauką „o celowym oddziaływaniu na układ stosunków społecznych" [Stankiewicz 2013: 201], które powoduje przekształcanie warunków życia ludności.

Zatem można przyjąć, że polityka społeczna jako dyscyplina naukowa, bada kwestie społeczne związane m.in. z polityką ludnościową, polityką rodzinną, polityką mieszkaniową, polityką zatrudnienia i dochodów, ochroną pracy, polityką wyżywienia ludności, zabezpieczeniem społecznym, ochroną zdrowia, prognozowaniem społecznym, jak też walką z patologią społeczną. Polityka społeczna jako teoria znajduje również zastosowanie m.in. przy tworzeniu programów społecznych lub gospodarczych.

Zdaniem Adama Kurzynowskiego polityka społeczna wobec osób niepełnosprawnych to "ogół działań podmiotów publicznych i organizacji pozarządowych, mających na celu tworzenie ogólnych warunków pracy, bytu i funkcjonowania osób niepełnosprawnych we wszystkich dziedzinach życia gospodarczego i społecznego, umożliwiających pełną integrację ze społeczeństwem" [Kurzynowski 1996: 21]. 
Katalog podstawowych kategorii teoretycznych, w odniesieniu do funkcjonujących definicji polityki społecznej odnosi się m.in. do:

- dobrobytu społecznego: Marshall T.H. (1967), Social Policy, London, Hutchinson University Library, s. 7; Rodgers B. (1979), The Study of Social Policy: A Comparative Approach, London, George Allen \& Unwin, s. 6; Szczepański J. (1981), Konsumpcja a rozwój człowieka. Wstęp do antropologicznej teorii konsumpcji, PWE, Warszawa, s. 336;

- bezpieczeństwa socjalnego: Ament E. (2000), Bold Relief: Institutional Politics and Origins of Modern American Social Policy, Princeton, Princeton University Press, s. 40; Szatur-Jaworska B., Firlit-Fesnak G. (1994), Leksykon pojęć socjalnych, IPS UW, Warszawa, s. 3; Esping-Andersen G. (1994), Welfare States and the Economy [w:] N.J. Smelser, R. Swedberg (red.), The Handbook of Economic Sociology, New York, Princenton University Press, Russel Sage Foundation, s. 711; Auleytner J. (2000), Strategia polityki społecznej [w:] Strategia rozwoju Polski do roku 2020, Dom Wydawniczy Elipsa, Warszawa, s. 169;

- socjalnych praw człowieka: Marshall T. H. (1970), Social Policy, London, Hutchinson University Library, s. 169; Auleytner J. (2000), Strategia polityki społecznej [w:] Strategia rozwoju Polski do roku 2020, Dom Wydawniczy Elipsa, Warszawa, s. 169;

- potrzeb: Supińska J. (1991), Polityki społecznej instrumenty (w:) Leksykon polityki społecznej, B. Rysz-Kowalczyk (red.), Oficyna Wydawnicza ASPRA-JR, Warszawa, s. 8; Szczepański J. (1981), Konsumpcja a rozwój człowieka. Wstęp do antropologicznej teorii konsumpcji, PWE, Warszawa, s. 336; Szubert W. (1979), Przedmiot, geneza i zakres socjalistycznej polityki społecznej [w:] Polityka społeczna, A. Rajkiewicz (red.), PWE, Warszawa, s. 34-36;

- sprawiedliwości społecznej: Szczepański J. (1981), Konsumpcja a rozwój człowieka. Wstęp do antropologicznej teorii konsumpcji, PWE, Warszawa, s. 336; Auleytner J. (2000), Strategia polityki społecznej [w:] Strategia rozwoju Polski do roku 2020, Dom Wydawniczy Elipsa, Warszawa, s. 169; Wnuk-Lipiński E. (1996), Demokratyczna rekonstrukcja, PWN, Warszawa, s. 63; Olędzki M. (1981), Wstęp do polityki społecznej. Propozycja wyjścia z kryzysu, PWE, Warszawa, s. 75-76; Townsend P. (1976), Sociology and Social Policy, Harmondsworth, Penguin Books, s. 6;

- integracji społecznej: Boulding K. (1967), Boundaries of social policy [w:] W.D. Birrell, P.A.R. Hillyard, A.S. Murie, D.J.D. Roche (red.), Social Administration: Readings in Applied Social Science, Harmondsworth, Penguin Books, s. 6;

- struktury społecznej: Kurzynowski A. (2001), Związki polityki społecznej z polityka gospodarcza [w:] Polityka społeczna, A. Kurzynowski (red.), Szkoła Główna Handlowa, Warszawa, s. 11; 
- kwestii społecznych: Danecki J. (1984), O postępie społecznym i polityce społecznej [w:] Polityka społeczna. Wybór tekstów teoretycznych, W. Anioł (red.), IPS, Warszawa, s. 191;

- postępu i rozwoju społecznego: Danecki J. (1980), Kilka uwag o polityce społecznej, [w:] Polityka spoteczna. Uwarunkowania demograficzne, zadania, potrzeby, M. Latuch, M. Namysłowska (red.), Książka i Wiedza, Warszawa, s. 51; Rajkiewicz A. (1984), Polityka społeczna-problemy izadania [w:] Polityka społeczna. Wybór tekstów teoretycznych, W. Anioł (red.), IPS UW, Warszawa, s. 69. Opracowanie własne na podstawie: Szarfenberg (2008), s. 63-68, 336-349, 360-391.

Instrumentami pozwalającymi skutecznie osiągać założone cele, a także realizować zadania polityki społecznej, są stanowione prawo i środki prawne, instytucje wypełniające zakres działania polityki społecznej, organizacje krajowe i międzynarodowe, indywidualne formy realizacji celów polityki społecznej, poradnictwo, upowszechnianie celów i zadań realizowanych przez mass media, działalność charytatywna, kształcenie kadr dla potrzeb polityki społecznej oraz działalność badawcza odnosząca się do problemów polityki społecznej [Stankiewicz 2013: 202].

\section{Podmioty polityki społecznej}

Kategorią pojęciową $\mathrm{w}$ nauce o polityce społecznej są podmioty polityki społecznej, których dominującą formą są skoordynowane oraz systematyczne działania zmierzające do określonego celu. Działania podmiotów - zgodne z obowiązującymi regulacjami prawnymi - obejmują zasięg globalny, europejski/regionalny (zasięg działań obejmuje obszar np. kilku krajów na kontynencie), krajowy (odnoszą się do działalności w obrębie granic kraju) oraz lokalny (działają na terytorium danego kraju, np. powiat, gmina) [Uścińska 2008: 73].

Podmiotem o zasięgu globalnym jest Organizacja Narodów Zjednoczonych (ONZ powołana w San Francisco 26 czerwca 1945 r.), w zakresie której najistotniejsze funkcje polityki społecznej pełnią:

- programy społeczne: Fundusz Organizacji Narodów Zjednoczonych Pomocy Dzieciom (UNICEF), Program Narodów Zjednoczonych ds. Rozwoju (UNDP), Fundusz Narodów Zjednoczonych dla Rozwoju Kobiet (UNIFEM), Ochotnicy Narodów Zjednoczonych (UNV), Fundusz Narodów Zjednoczonych ds. Działalności Populacyjnej (UNFPA), Międzynarodowy Program ONZ ds. Kontroli Narkotyków (UNDCP), Światowy Program Żywności (WFP), Urząd Wysokiego Komisarza ONZ ds. Uchodźców (UNHCR), Uniwersytet Organizacji Narodów Zjednoczonych (UNU), Instytut Narodów Zjednoczonych dla Szkolenia 
i Badań (UNITAR), Instytut Badawczy Narodów Zjednoczonych dla Rozwoju Społecznego (UNRISD);

- organizacje wyspecjalizowane: Międzynarodowa Organizacja Pracy (ILO), Organizacja Narodów Zjednoczonych ds. Wyżywienia i Rolnictwa (FAO), Organizacja Narodów Zjednoczonych ds. Oświaty, Nauki i Kultury (UNESCO), Światowa Organizacja Zdrowia (WHO), Międzynarodowy Bank Odbudowy i Rozwoju (IBRD), Międzynarodowy Fundusz Walutowy (IMF) (Ibidem, s. 542).

Zgromadzenie Ogólne Narodów Zjednoczonych 13 grudnia 2006 r. przyjęło Konwencję o prawach osób niepełnosprawnych [Zawadzki 2010: 61], która określiła kierunek „nowoczesnego” podejścia do niepełnosprawności, „od podejścia opiekuńczego i charytatywnego do tworzenia społeczeństwa i środowiska otwartego dla wszystkich, włączającego i wyrównującego szanse, opartego na prawach człowieka" [http://www.pfon.org/dokumenty-i-publikacje/konwencja-onz/91-konwencja-onz-o-prawach-osob-niepelnosprawnych, dostęp: 15.05.2017].

Z kolei europejskie podmioty polityki społecznej stanowią:

- Rada Europy - organizacja powołana w 1949 r. w Londynie, priorytetem jej jest „promocja powszechnego systemu ochrony społecznej” [Uścińska 2008: 77]; najważniejsze regulacje prawne w zakresie polityki społecznej to m.in.: Europejska Konwencja o Pomocy Społecznej i Medycznej (1953), Europejska Karta Społeczna (1961, zrewidowana w 1966 r.), Europejski Kodeks Zabezpieczenia Społecznego (1964, zrewidowany w 1990 r.), Europejska Konwencja o Zabezpieczeniu Społecznym (1972), Europejska Konwencja o Statusie Prawnym Pracownika Migrującego (1977), Europejska Karta Samorządu Terytorialnego (1985);

- Unia Europejska - organizacja (związek państw) utworzona 1 listopada 1993 r. na mocy podpisanego 7 lutego 1992 r. Traktatu z Maastricht, siedzibą jest Bruksela; podstawowe regulacje dotyczące polityki społecznej zawarte są m.in. w: Traktacie ustanawiającym Wspólnotę Europejską z 1957 r., Wspólnotowej Karcie Podstawowych Praw Społecznych Pracowników z 1989 r., Traktacie o Unii Europejskiej z 1992 r., Karcie Praw Podstawowych Unii Europejskiej z 2000 r. [Uścińska 2013: 164].

Europejska strategia w sprawie niepełnosprawności 2010-2020 określa działania i mechanizmy potrzebne do wdrażania Konwencji o prawach osób niepełnosprawnych ONZ w Unii Europejskiej. Strategia wzywa do działania na rzecz tworzenia Europy bez barier dla wszystkich jej obywateli. Dokument przypomina, że na państwach członkowskich Unii Europejskiej spoczywa odpowiedzialność za poprawę społecznej i ekonomicznej sytuacji osób niepełnosprawnych [http://www.pfon.org/dokumenty-i-publikacje/konwencja-onz/91-konwencja-onz-o-prawach-osob-niepelnosprawnych, dostęp: 15.05.2017]. 
W kształt polityki społecznej wpisane są określone zadania państwa, które realizowane są za pomocą specjalnie utworzonego aparatu - podmiotów. Państwowe podmioty polityki społecznej w Polsce dzielą się na:

1. Podmioty ustawodawcze:

- Sejm: Komisja do Spraw Kontroli Państwowej; Komisja do Spraw Unii Europejskiej; Komisja Edukacji, Nauki i Młodzieży; Komisja Finansów Publicznych; Komisja Gospodarki i Rozwoju; Komisja Kultury Fizycznej, Sportu i Turystyki; Komisja Kultury i Środków Przekazu; Komisja Łączności z Polakami za Granicą; Komisja Mniejszości Narodowych i Etnicznych; Komisja Odpowiedzialności Konstytucyjnej; Komisja Polityki Senioralnej; Komisja Polityki Społecznej i Rodziny; Komisja Rolnictwa i Rozwoju Wsi; Komisja Samorządu Terytorialnego i Polityki Regionalnej; Komisja Spraw Zagranicznych; Komisja Sprawiedliwości i Praw Człowieka; Komisja Ustawodawcza; Komisja Zdrowia;

- Senat: Komisja Budżetu i Finansów Publicznych; Komisja Gospodarki Narodowej i Innowacyjności; Komisja Kultury i Środków Przekazu; Komisja Nauki, Edukacji i Sportu; Komisja Obrony Narodowej; Komisja Praw Człowieka, Praworządności i Petycji; Komisja Rodziny, Polityki Senioralnej i Społecznej; Komisja Rolnictwa i Rozwoju Wsi; Komisja Samorządu Terytorialnego i Administracji Państwowej; Komisja Spraw Emigracji i Łączności z Polakami za Granicą; Komisja Spraw Zagranicznych i Unii Europejskiej; Komisja Środowiska; Komisja Ustawodawcza; Komisja Zdrowia;

2. Podmioty wykonawcze:

- prezydent Rzeczypospolitej Polskiej

- prezes Rady Ministrów (Premier)

- ministrowie

3. Podmioty kontrolne:

- Najwyższa Izba Kontroli

- Rzecznik Praw Obywatelskich

- Rzecznik Praw Dziecka

- Państwowa Inspekcja Pracy

4. Podmioty sądownicze:

- Trybunał Konstytucyjny

- Sądy Pracy i Ubezpieczeń Społecznych

- Sądy Rodzinno-Opiekuńcze [www.sejm.gov.pl, dostęp: 19.05.2017].

Za wykonywanie zadań publicznych odpowiedzialna jest lokalna polityka społeczna, realizowana przez samorząd terytorialny (rada gminy, rada powiatu, sejmik województwa) [Kulesza 2013: 12-21], którego zadania i kompetencje reguluje Konstytucja Rzeczypospolitej Polskiej z dnia 2 kwietnia 1997 r. (Dz. U. z 1997 r. Nr 78, poz. 483; z 2001 r. Nr 28, poz. 319; z 2006 r. Nr 200, poz. 1471; z 2009 r. Nr 114, poz. 946). 
Pozapaństwowe (niepubliczne) podmioty polityki społecznej, działające w ramach lokalnej polityki społecznej, „zaliczane są do «trzeciego sektora» jako podmioty realizujące zadania publiczne (...), a rola organizacji społecznych jest na tyle ważna, że niektóre ustawy wprost wskazują jako wykonawców zadań organizacje pozarządowe, którym organy administracji rządowej i samorządowej mogą zlecać określone zadania, udzielając dotacji na finansowanie lub dofinansowanie realizacji zadania zleconego organizacjom pozarządowym" [Kulesza 2013: 24].

Sporządzanie planów polityki społecznej w odniesieniu do osób niepełnosprawnych spoczywa na rządzie, powiecie, gminie oraz organizacjach. Działania mające na celu wdrażanie Standardowych Zasad ONZ dotyczą: współpracy z organizacjami osób niepełnosprawnych jako równymi partnerami; analizowania wraz z organizacjami osób niepełnosprawnych własnych działań w celu zbadania przestrzegania Zasad Standardowych; tworzenia wraz z organizacjami osób niepełnosprawnych spisu potrzeb osób niepełnosprawnych; zmniejszania przepaści pomiędzy obecnymi zasobami a potrzebami osób niepełnosprawnych w odrębnym planie polityki wobec osób niepełnosprawnych; określenia w planie sposobu uwzględniania aspektów dotyczących osób niepełnosprawnych we wszystkich podejmowanych w przyszłości decyzjach; określenia w planie, jak rozwijać się będzie w przyszłości współpraca z organizacjami osób niepełnosprawnych; okresowego, regularnego oceniania oraz rewizji planu polityki wobec osób niepełnosprawnych [Agenda 22. Wytyczne dla władz lokalnych w zakresie planowania polityki wobec osób niepełnosprawnych, tłum. Urząd Miasta Gdyni (za zgodą Szwedzkiej Federacji Osób Niepełnosprawnych), 2001].

\section{Działania na rzecz osób niepełnosprawnych}

Niezwykle istotnymi zadaniami polityki społecznej są działania na rzecz wyrównywania szans osób z niepełnosprawnością. Podejmowane są one na gruncie międzynarodowym (m.in. dzięki Powszechnej Deklaracji Praw Człowieka z 1948 r., Międzynarodowym Paktom Praw Człowieka z 1966 r., Deklaracji Praw Osób Umysłowo Upośledzonych z 1971 r., Deklaracji Praw Osób Niepełnosprawnych z 1975 r., Standardowym Zasadom Wyrównywania Szans Osób Niepełnosprawnych z 1993 r.) oraz europejskim (m.in. dzięki Konwencji o Ochronie Praw Człowieka i Podstawowych wolności z 1950 r., Europejskiej Karcie Społecznej z 1961 r., Zleceniu w sprawie Spójnej Polityki wobec Osób Niepełnosprawnych z 1992 r., Zleceniu w sprawie Planu Działania na rzecz promocji praw i pełnego uczestnictwa osób niepełnosprawnych i poprawy jakości życia osób niepełnosprawnych w Europie z 2006 r.) [Firlit-Fesnak, Magnuszewska-Otulak 2013: 270-272]. 
Konstytucja Rzeczypospolitej Polskiej gwarantuje osobom niepełnosprawnym prawo do niedyskryminacji (art. 32), nakłada także na władze publiczne obowiązek zapewnienia szczególnej opieki zdrowotnej osobom niepełnosprawnym (art. 68), jak też obowiązek pomocy tym osobom w zabezpieczeniu egzystencji, przysposobieniu do pracy i komunikacji społecznej (art. 69) (Konstytucja Rzeczypospolitej Polskiej z dnia 2 kwietnia 1997 r.; Dz.U. z 1997 r. Nr 78, poz. 483; z 2001 r. Nr 28, poz. 319; z 2006 r. Nr 200, poz. 1471; z 2009 r. Nr 114, poz. 946).

Uchwalona przez Sejm Karta Praw Osób Niepełnosprawnych zawiera kata$\log 10$ praw, wskazując najważniejsze obszary, w których niezbędne są działania państwa. Dokument podkreśla także, że „osoby niepełnosprawne mają prawo do niezależnego, samodzielnego i aktywnego życia oraz nie mogą podlegać dyskryminacji" [Biuro Pełnomocnika Rządu ds. Osób Niepełnosprawnych; http://www. niepelnosprawni.gov.pl/p,94,uprawnienia-osob-niepelnosprawnych, dostęp: 22.05.2017].

Kolejnym aktem prawnym, regulującym pomoc osobom niepełnosprawnym, jest Ustawa o rehabilitacji zawodowej i społecznej oraz zatrudnianiu osób niepełnosprawnych stanowiąca, że rehabilitacja osób niepełnosprawnych to zespół działań organizacyjnych, leczniczych, technicznych, psychologicznych, szkoleniowych, edukacyjnych i społecznych, które zmierzają do osiągnięcia najwyższego poziomu ich funkcjonowania, jakości życia oraz integracji społecznej (art. 7) (Ustawa z dnia 27 sierpnia 1997 r. o rehabilitacji zawodowej i społecznej oraz zatrudnianiu osób niepełnosprawnych; Dz. U. z 2016 r., poz. 2046, 1948).

Przesłankami udzielania wsparcia osobom niepełnosprawnym w myśl Ustawy o pomocy społecznej jest m.in. „prowadzona przez pracowników socjalnych i instytucje pomocy społecznej rehabilitacja społeczna (..) wyrażająca się w prowadzeniu pracy socjalnej na rzecz niepełnosprawnych, poradnictwie prawnym czy pedagogicznym, a także przez dofinansowanie uczestnictwa w turnusach rehabilitacyjnych czy organizowanie i finansowanie warsztatów terapii zajęciowej" [Kulesza 2013: 67] oraz tworzenie mieszkań chronionych, umożliwiających podopiecznym przygotowanie się do samodzielnego funkcjonowania w środowisku.

Na szczególną uwagę zasługują organizacje pozarządowe, bardzo często zrzeszające osoby niepełnosprawne, bardzo aktywne w organizowaniu działań na rzecz osób niepełnosprawnych, ,"które tworzą i prowadzą ośrodki wczesnej interwencji, ośrodki wsparcia, warsztaty terapii zajęciowej, dzienne centra aktywności, środowiskowe domy samopomocy oraz prowadzą szkolenia, programy edukacyjno-rehabilitacyjne, jak tez działają aktywnie na rzecz integracji osób niepełnosprawnych" [Ibidem, s. 68].

Podstawą kształtowania się polityki społecznej w odniesieniu do modelu społecznego niepełnosprawności - zdaniem Barbary Gąciarz - jest definiowanie pojęcia stanowiącego podstawę dla zobowiązań „władz publicznych, a tym sa- 
mym zakres zadań publicznych i charakter aktywności wielu instytucji" [Gąciarz 2014a: 25]. W wymiarze indywidualnym definiowanie niepełnosprawności „polega na nadawaniu lub nienadawaniu statusu prawnego osoby niepełnosprawnej, kwalifikującego lub nie do grupy beneficjentów określonych świadczeń społecznych" [Ibidem]. Zatem formalno-prawne aspekty niepełnosprawności wpływają na podejmowanie decyzji o udzielaniu lub nieudzielaniu wsparcia, co staje się kluczowe dla obecnej polityki społecznej.

\section{Bibliografia}

Ament E. (2000), Bold Relief: Institutional Politics and Origins of Modern American Social Policy, Princeton University Press, Princeton.

Auleytner J. (2000), Strategia polityki społecznej [w:] Strategia rozwoju Polski do roku 2000, Dom Wydawniczy ELIPSA, Warszawa.

Boulding K. (1967), Boundaries of social policy [w:] Social Administration: Readings in Applied Social Science, W.D. Birrell, P.A.R. Hillyard, A.S. Murie, D.J.D. Roche (red.), Penguin Books, Harmondsworth.

Danecki J. (1980), Kilka uwag o polityce społecznej [w:] Polityka społeczna. Uwarunkowania demograficzne, zadania, potrzeby, M. Latuch, M. Namysłowska (red.), Książka i Wiedza, Warszawa.

Danecki J. (1984), O postępie społecznym i polityce społecznej [w:] Polityka społeczna. Wybór tekstów teoretycznych, W. Anioł (red.), IPS, Warszawa.

Esping-Andersen G. (1994), Welfare States and the Economy [w:] The Handbook of Economic Sociology, N.J. Smelser, R. Swedberg (red.), Princenton University Press, Russel Sage Foundation, New York.

Firlit-Fesnak G., Magnuszewska-Otulak G. (2013), Dyskryminacja a równouprawnienie; zadania polityki społecznej [w:] Polityka społeczna. Podręcznik akademicki, G. Firlit-Fesnak, M. Szylko-Skoczny (red.), Wydawnictwo Naukowe PWN, Warszawa.

Gąciarz B. (2014a), Model społeczny niepetnosprawności jako podstawa zmian w polityce społecznej [w:] Polscy niepetnosprawni. Od kompleksowej diagnozy do nowego modelu polityki społecznej, B. Gąciarz, S. Rudnicki (red.), Wydawnictwa AGH, Kraków.

Gąciarz B. (2014b), W stronę nowego modelu polityki społecznej wobec niepetnosprawności. Kilka słów o projekcie badawczym, „Niepełnosprawność - Zagadnienia, Problemy, Rozwiązania”, z. 2/2014(11).

Kulesza E. (2013), Lokalna polityka społeczna, Drukarnia Wydawnicza TRANS-DRUK, Warszawa.

Kurzynowski A. (1996), Osoby niepetnosprawne w polityce społecznej [w:] Polityka społeczna wobec osób niepetnosprawnych, J. Mikulski, J. Auleytner (red.), Wyższa Szkoła Pedagogiczna TWP, Warszawa.

Kurzynowski A. (2001), Związki polityki społecznej z polityka gospodarcza [w:] Polityka społeczna, A. Kurzynowski (red.), Szkoła Główna Handlowa, Warszawa.

Marshall T.H. (1967), Social Policy, Hutchinson University Library, London.

Marshall T. H. (1970), Social Policy, Hutchinson University Library, London. 
Marska-Dzioba N. (2011), W cieniu reformy emerytalnej. Przejrzystość finansowania polityki integracji osób niepetnosprawnych, Polskie Towarzystwo Ekonomiczne, Zeszyty Naukowe nr 11, Kraków.

Obuchowski K. (1999), Polityka społeczna z punktu widzenia psychologa osobowości [w:] Teoretyczne problemy nauki o polityce społecznej, J. Auleytner, J. Danecki (red.), Dom Wydawniczy ELIPSA, Warszawa.

Olędzki M. (1981), Wstęp do polityki społecznej. Propozycja wyjścia z kryzysu, PWE, Warszawa.

Rajkiewicz A. (1984), Polityka społeczna - problemy i zadania [w:] Polityka społeczna. Wybór tekstów teoretycznych, W. Anioł (red.), IPS UW, Warszawa.

Rodgers B. (1979), The Study of Social Policy: A Comparative Approach, George Allen \& Unwin, London.

Sala K. (2016), Polityka społeczna wobec osób niepetnosprawnych, „Wrocławskie Studia Politologiczne", nr 21, Wrocław.

Stankiewicz L.M. (2013), Vademecum do pracy socjalnej, Wydawnictwo Uniwersytetu Warmińsko-Mazurskiego w Olsztynie, Olsztyn.

Supińska J. (1991), Polityki społecznej instrumenty [w:] Leksykon polityki społecznej, B. Rysz-Kowalczyk (red.), Oficyna Wydawnicza ASPRA-JR, Warszawa.

Szarfenberg R. (2008), Krytyka i afirmacja polityki społecznej, Wydawnictwo Instytutu Filozofii i Socjologii PAN, Warszawa.

Szatur-Jaworska B., Firlit-Fesnak G. (1994), Leksykon pojęć socjalnych, IPS UW, Warszawa.

Szczepański J. (1981), Konsumpcja a rozwój człowieka. Wstęp do antropologicznej teorii konsumpcji, PWE, Warszawa.

Szubert W. (1979), Przedmiot, geneza i zakres socjalistycznej polityki społecznej [w:] Polityka społeczna, A. Rajkiewicz (red.), PWE, Warszawa.

Townsend P. (1976), Sociology and Social Policy, Penguin Books, Harmondsworth.

Uścińska G. (2008), Międzynarodowe podmioty polityki społecznej a wspótczesne wyzwania społeczne [w:] Wokót polityki społecznej, K. Głąbicka, M. Grewiński (red.), Wydawnictwo Politechniki Radowskiej, Warszawa.

Uścińska G. (2013), Międzynarodowe standardy i formy wspótpracy w polityce społecznej oraz ich wptyw na Polskę [w:] Polityka społeczna. Podręcznik akademicki, G. Firlit-Fesnak, M. Szylko-Skoczny (red.), Wydawnictwo Naukowe PWN, Warszawa.

Wnuk-Lipiński E. (1996), Demokratyczna rekonstrukcja, PWN, Warszawa.

Zawadzki P.W. (2010), Instytucje międzynarodowe w walce z ubóstwem i wykluczeniem [w:] Polityka publiczna wobec ubóstwa i wykluczenia społecznego, R. Szarfenberg, C. Żołędowski, M. Theiss (red.) Dom Wydawniczy ELIPSA, Warszawa.

\section{Akty prawne}

Konstytucja Rzeczypospolitej Polskiej z dnia 2 kwietnia 1997 r. (Dz. U. z 1997 r. Nr 78, poz. 483; z 2001 r. Nr 28, poz. 319; z 2006 r. Nr 200, poz. 1471; z 2009 r. Nr 114, poz. 946).

Ustawa z dnia 27 sierpnia 1997 r. o rehabilitacji zawodowej i społecznej oraz zatrudnianiu osób niepełnosprawnych (Dz. U. z 2016 r., poz. 2046, 1948).

Ustawa z dnia 12 marca 2004 r. o pomocy społecznej (Dz. U. z 2016 r., poz. 930, 1583, 1948, 2174; z 2017 r., poz. 38). 
Konwencja o prawach osób niepełnosprawnych, sporządzona w Nowym Jorku dnia 13 grudnia 2006 r., ogłoszona 25 października 2012 r. (Dz. U. z 2012 r., poz. 1169).

Karta Praw Osób Niepełnosprawnych z dnia 1 sierpnia 1997 r. (M.P. z 13.08.1997 r., Nr 50, poz. 475).

Agenda 22. Wytyczne dla władz lokalnych w zakresie planowania polityki wobec osób niepełnosprawnych, tłum. Urząd Miasta Gdyni (za zgodą Szwedzkiej Federacji Osób Niepełnosprawnych), 2001.

\section{Netografia}

http://www.niepelnosprawni.gov.pl/p,94,uprawnienia-osob-niepelnosprawnych.

http://www.pfon.org/dokumenty-i-publikacje/konwencja-onz/91-konwencja-onz-o-prawachosob-niepelnosprawnych.

http://www.sejm.gov.pl. 